\title{
Error Analysis of Students' Speaking Performances Through Phonological Elements
}

\author{
Prasetya Muntiarini ${ }^{1}$, Winantu K. S. A ${ }^{2}$, Wiwin Widyawati ${ }^{3}$ \\ muntiariniprasetya@gmail.com ${ }^{1}$,winantu@iainponorogo.ac.id ${ }^{2}$,winwidya75@gmail.com³ \\ IAIN Ponorogo ${ }^{1}$, IAIN Ponorogo ${ }^{2}$, IAIN Ponorogo ${ }^{3}$ \\ Corresponding Author winantu@iainponorogo.ac.id
}

\begin{abstract}
The principal part in communication is speaking. Therefore, the communicants such second language learners have to be able to speak fluently that represented speaking elements namely pronunciation, stressing, intonation, and juncture. This research focused on the analysis of errors on students' speaking performance through phonological elements and the causes of those errors of the tenth grade at SMAN 1 Sambit Ponorogo in academic year 2018/2019. The data were collected through observation, interview, and documentation. Then, typology technique was applied to analyze the data. The result indicated that the students mostly were making errors where performing speaking in class. The errors can be seen in term of speaking elements and they were categorized into omission, addition, mis-formation, and mis-ordering. Meanwhile, the errors were caused by L1 interference that affected by the usage of mother tongue and developmental error that represented misconception of grammatical rules when performing their speaking.
\end{abstract}

Keywords: oral communication, pronunciation error, phonological elements

\section{Introduction}

As foreign language learners, the students must show their ability in speaking fluently because this becomes a complex task in understanding the nature of speaking. The task related to distinctive speaking purposes that involves in different skills [1]. Otherwise, integrated skills were needed in spoken English and it depends on communicative purposes. Each communicative purpose, speaking skill holds up the second language learners in expressing the thoughts and its meanings. As the consequently, the speakers should deliver the speaking constituents correctly such as pronunciation, intonation, stressing, and juncture [2] in their speaking performances since the audiences catch the message of their ideas within effortless.

Pronunciation is the way of saying the words and in English mostly they have different and same sounds such record which has same written and different pronunciation for verb /ri-'kórd/and noun /'re-kərd/. Therefore, pronunciation becomes one of speaking constituent that required to be presented obviously. In teaching English as second language, teacher must explore the components of grammar as the pronunciation aspects and teacher gives greater opportunities to second language learners in practicing their speaking skill prosperous [3]. Moreover, the students must consider their pitch in raising and down their voice that known as intonation [3]. The difference pitch occurs when asking and stating utterances for instance. The next speaking component is stressing which commonly used to highlight the sound. In other word, stressing could occur in different syllables such first, middle, or last by saying louder at one [3]. For example the word HAPpy, the stressing takes place in the first syllable while the word deCIDE is taken place in last syllable. The last speaking component is juncture which the label given to a number of features which may occur at the boundary between two words in connected speech such that, even though the two words may be fully linked together, the boundary between them is nevertheless unambiguous and clear [4].

Practically, the students perform English presentations in their English subject and errors were produced without students realized. Indeed, error can be identified as an affirmation both procedures and the standardized [5]. For instance, in performing speaking, the learners know the way to pronounce the words however juncture and stressing cannot be produced competently by the learners and the intonation does. In this case, one of the objects of this research showed the error in producing her utterance such

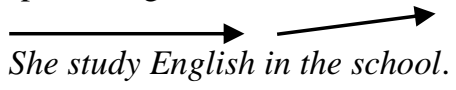


Some errors occurred in that utterance. The first is the word studies /'st $\Lambda$ dis/ was pronounced /'st $\mathbf{A d i} /$. It determined as pronunciation error of omission since the nonexistence of $/ \mathrm{s} /$ in that word. The intonation error produced in the last of the utterance. Raising intonation occurred eventhough the utterance is declarative term. Hence, it could be classified into mis-formation error whereas she applied incorrect intonation just as saying that utterance. Furthermore, stressing errors occurred when the students said study English. The accents were put inappropriate place. In this case, the student said stuDY meanwhile the word English placed in the second syllable. It means incorrect replacements of those words are categorized into mis-ordering error since the correct stressing replacement must be taken in first syllables such STUdy and ENGlish. The last error is juncture such showed in the phrase the//school. In performing this phrase, she taken juncture between the and school. Meanwhile, juncture should not be placed, hence the student made addition error.

The cases above become the researchers consideration taking a research related to this topic. Since these errors caused the students have unsuccessful communication and the message can be delivered prosperously.

\section{Research method}

This research was case study since the aims of this research was to explain the pronunciation error by looking the process of students' speaking performance. This research analyze some variables such students' pronunciation from their speaking performance and the causes of errors. Descriptive qualitative was appropriate in conducting this current research. The object was the tenth grade students at SMAN 1 Sambit Ponorogo and the majority was science. The students in this class show their intentions in speaking but they often produce some errors in their speaking and it becomes the researcher consideration. Moreover, the data in this research were collected through transcript of observation, documentation and interview that were transcribed. Then those data were analyzed by using typology method [6] by grouping the error based on phonological elements and the theory of error by Dulay.

\section{Result and discussion}

Here, the researcher identified the data into two categories; students' error on speaking elements and the causes of those errors as explain distinctly in the following explanation.

\subsection{The classification of students' speaking error}

There were 25 videos of students' speaking performances as collected data and those were classified into four speaking aspects namely pronunciation, stressing, intonation, and juncture and they were analyzed through the theory of error promoted by Dulay.

Pronunciation error. The researchers found 170 data of pronunciation represented the error. They broke down into four classifications. 45 data represented omission error, 29 data showed addition error, 95 data were misformation, and 1 data stood for mis-ordering error.

Ommission. This means unavailability of the entity in slightly construction of an utterance [7]. The errors appear when the students replaced letter $/ \mathrm{s} /$ in the last word, $/ \mathrm{j} /, / \mathrm{a} /$, and $/ \mathrm{\mho} /$ in the middle of the words such the following samples taken from the data:

The lexeme download /daun'lood/ was uttered /dan'lod/ and omission error occurred in this word since diphthong / $/ \mathrm{r}$ replaced from this word. The similar case also found in pronouncing online /an'lain/ into /an'lan/. In this occasion, vowel /I/ omitted when the student producing this sound. The next is reducing consonant /j/ in pronouncing the word document /'d $\alpha$ :kjumənt/ became /'d $\alpha$ :kumənt/. Meanwhile, the student also made an omission error when she produced the word transportation/trænspo:r'ter $\int \mathrm{n} /$ into /tranpo:r'ter $\int \mathbf{n} /$ since the student omitted consonant $/ \mathrm{s} /$. The next is lexeme much $/ \mathrm{m} \Lambda \mathrm{t} /$ t that was produced $/ \mathbf{m s t} /$. Omission error occurred when consonant /S/ omitted. 
Addition. Addition errors are opposite of omission. They are characterized by the presence of an item which must not appear in a well-formed utterance [7]. The data showed mostly the students put on /ed/ in the end of the word. In addition, they also added vowel /a/ and /e/ in the middle of the lexeme such taken from the data as follows:

In this case, lexeme caused /ko:zt/ was sounded /ko:zed/. Vowel /e/ was added in the middle of the sound and also consonant /d/ was put on in the last word. It means the student made error in pronouncing this word and it was classified into addition error. The other addition error was occurred when the students sounded offered /'o:ford/ into /'o:fared/. Here, the pronunciation was as same as English written in which vowel /e/ and consonant /d/ appeared in the end of this word. The next addition error is click/klik/ that was said / kelık/. In this case, vowel /e/ was added in producing this word.

Mis-formation. Mis-formation errors means signalized entity by inappropriate morpheme or interchangeable structure [7]. This form can be identified when the sound $/ \Lambda /$ into $/ 0 /$ and $/ z /$ into $/ \mathrm{s} /$ such the following examples:

In pronouncing upload / $\mathrm{ppload/,} \mathrm{the} \mathrm{student} \mathrm{produced} \mathrm{sound} \mathrm{/ \Lambda plud/.} \mathrm{Incorrect} \mathrm{entity} \mathrm{occurred} \mathrm{such} \mathrm{vowel} \mathrm{/u/}$ replaced vowel $/ \mathrm{o} /$ and $/ \mathrm{a} /$ in this morpheme. Since this condition made mis-formation error occurred in producing the sound. Then, morpheme picture /'prktfər/ was sounded /prktur/. Mis-formation error occurred since vowel /ə/ was replaced by /u/. The next mis-formation error also occurred when the student pronounced fast /fa:st/ into /fe:st/. In this case, the students used vowel /e/ to replace vowel /a:/ in sounding that morpheme. The last example represented mis-formation error was all / $\mathrm{s}: 1 /$. Here, the student produced that word into /all/ and incorrect form showed when he replaced vowel $/ \mathrm{s} / /$ into $/ \alpha /$.

Mis-ordering This term is signalized by inappropriate morpheme replacement in utterance [7]. In this case, mis-ordering error arose when the student pronounced April /'epril/ into /'erprel/. The incorrect replacement of vowel /I/ after /e/ caused mis-ordering error produced in sounding this word.

Intonation Error. There were 30 intonation errors which were classified into four types. Those were omission, addition, mis-formation, and mis-ordering. Apparently, findings about all intonation error below were classified into 2 kinds namely 27 data of mis-formation error and 3 data of mis-ordering error.

Mis-formation. Mis-formation errors means signalized entity by inappropriate morpheme or interchangeable structure [7] such the following examples taken from the data

In producing the utterance Application telegram can be used to send message, picture, video and music the student used flat intonation that drawn below

$$
\overrightarrow{\text { Application telegram can be used to send message, picture, video and music }}
$$

Meanwhile, the intonation must be in three classifications raising in the first morpheme then flat intonation, continued with raising intonation and ended within falling intonation as follow

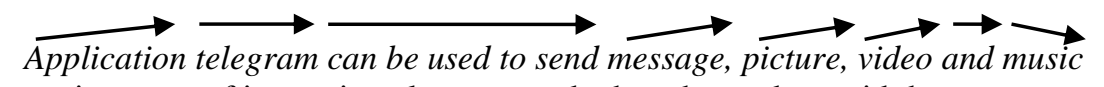

The other mis-formation error of intonation also occurred when the student said the utterance recommended for gaming, editing and programming. Here, the utterance was produced by using flat intonation.

$\overrightarrow{\text { It recommended for gaming, editing and programming }}$

Whereas, the student must produced the utterance such

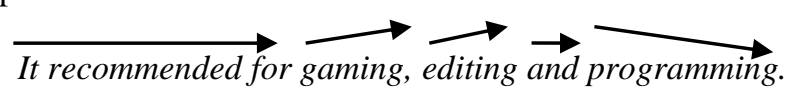

Mis-ordering. This term is signalized by inappropriate morpheme replacement in utterance [7]. It means learners chose correct intonation but they put in incorrect place. In this occasion, the student chose raising and flat intonation in the following utterance however she used those intonations in incorrect place.

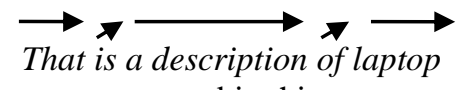

Because of this intonation, mis-ordering error appeared in this utterance. The student must be said the utterance such the description below

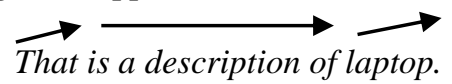

The other example of mis-ordering error occurred when the student said the following utterance 


\section{$\overrightarrow{\text { Such as }} \underset{\text { uploading, chatting and update status. }}{\longrightarrow}$}

Here, he chose appropriate intonation such raising, flat, and falling intonation whereas he put on them incorrect place. The student must be put falling intonation on the words uploading, chatting, update. The flat intonation was used in words such as, and. While falling intonation put on the word status such the description below

\section{$\overrightarrow{\text { Such as }} \overrightarrow{\text { uploading, }} \underset{\text { chatting and update status. }}{\longrightarrow}$}

Stressing error. In this case, the researchers found 41 stressing errors whereas all those data were categorized into mis-ordering error. Mis-ordering errors are signalized by inappropriate morpheme replacement in utterances [7]. Mis-ordering error in stressing occurred when students distress in the wrong syllables, for instance the stressing must be taken in the first syllable but it put in whether the third or second syllable such the following example taken from the data

In this part, teacher asked the students practicing one of parts of speech (noun) consisted of two syllables. Most of them placed the stressing in second syllable even the correct one was taken place in first syllable. Here, the stressing was emphasized in the second syllable such daTA, homeWORK, mesSAGE, whatsAPP, worldWILD. Those incorrect placement of stressing caused mis-ordering error. Meanwhile, the correct stressing must be put in the first syllable such DAta, HOMEwork, MESsage, WHATSapp, WORLDwild.

Furthermore, teacher asked the students practicing one of parts of speech (adverb) consisted of four syllables. Most of them placed the stressing in first syllable even the correct one was taken place in third syllable. Here, the stressing was emphasized in the first syllable such Initially, OFficially, and Relatively. Those incorrect placement of stressing caused mis-ordering error. Meanwhile, the correct stressing must be put in the third syllable such iniTIALly, offiCIALly, and relaTIVEly.

In addition, teacher also asked the students practicing one of parts of speech (noun) consisted of five syllables. Most of them placed the stressing in first syllable even the correct one was taken place in fourth syllable. Here, the stressing was emphasized in the first syllable such COMmunication, ORganization, VErification, SPEcification. Those incorrect placement of stressing caused mis-ordering error. Meanwhile, the correct stressing must be put in the fourth syllable such communiCAtion, organiZAtion, verifiCAtion, specifiCAtion.

Juncture. The researchers found 10 data of juncture represented the error and they were categorized into misordering error. Mis-ordering errors are signalized by inappropriate morpheme replacement in utterances [7]. Mis-ordering existed if juncture put in incorrect placement when producing an utterance. In this occasion, the researchers identified the students put juncture in the middle even the correct one was taken place in the last such the following examples taken from the students' speaking performances

In producing the phrase snowstorm, the students must be taken juncture in the end of the phrase snowstorm\| since it represented one meaning, whereas they put juncture between snow $\|$ storm $\|$ that represented different meaning. Furthermore, the word click consist of one syllable, hence the juncture must be taken place in the last word click $\|$. In this case the students put juncture such $c e\|k l i k\|$. Then, they also put the juncture in incorrect place when produce the word help. The correct juncture must be put in the end of the word because it consist of one syllable but the students took the juncture between he $\|$ lep $\|$. The other example, of correct juncture was Click \| but student produced it $\boldsymbol{C e} \|$ lick. Then, the correct juncture was Help \| but student produced it $\boldsymbol{H e} \|$ lep. The next, the correct juncture was Holding $\|$ but it was produced $\mathbf{H o l} \|$ ding by the student. The last, the correct juncture was Used $\|$ but it was produced $\mathbf{U} \|$ sed by the student. Through that all examples above, it categorized in misordering error of juncture because the students produced juncture in the middle of the word even the correct was the juncture had to be produced in the end of the word.

\subsection{The causes of error}

L1 Interference. As second language learner, the students have to conscious about second language knowledge. Practically, first language affected learners in practicing second language such language construction, diction, and accent [8]. They promote errors when learners using L2. According to the data of interview, the researchers considered that they are two points of view in promoting students' error as the following explanation

Listen Native Speaker Barely. Listening and reading are others English skills that support students in improving students' speaking skill. Based on the interview data, mostly the tenth grade students at SMA 1 Sambit 
confessed they were hardly ever listening native speaker such. The students usually watched movie, news report, and music but they just read the subtitle.

Practice Speaking Skill Rarely. The students argued they never join English extracurricular. In hence, they only practice their speaking in class. Furthermore, the students also claimed that they never used English whether in class or outside class the student only practice speaking in the class.

Developmental error. Developmental error is the causes of error in which the students used incorrect grammatical rules of second language [8]. In this case, the researchers identified that the students found difficulties in differentiate English structure for instance the usage of plural and singular form, regular and irregular verb and so forth. Generally, those patterns affected phonological aspects such pronunciation, stressing, intonation, and juncture.

\section{Conclusion}

Through phonological aspects, the researchers sum up from 170 pronunciation errors were classified into 45 data of omission, 29 data of addition, 95 data of mis-formation, and 1 datum of mis-ordering. Moreover, 30 intonation errors were classified into 27 data of mis-formation (27 errors) and 3 data of mis-ordering. In addition, 41 errors of stressing word and 10 errors of juncture were found and they included mis-ordering error. Meanwhile, L1 interference and developmental error become the causes of error in performing speaking.

\section{References}

[1] J. C. Richards and W. A. Renandya, Methodology in language teaching: an anthology of current practice. Cambridge, UK; New York: Cambridge University Press, 2002.

[2] H. D. Brown and P. Abeywickrama, Language assessment: principles and classroom practice (2nd). New York: Longman, 2011.

[3] G. Kelly, How to Teach Pronunciation (With Cd). Pearson Education India, 2006.

[4] 'Errors in Juncture Made by Iraqi EFL University Students', 2011.

[5] S. P. Corder, 'Error Analysis and Interlanguage', Appl. Linguist., vol. 2, 1976.

[6] J. A. Hatch, Doing qualitative research in education settings. Albany: State University of New York Press, 2002.

[7] H. Dulay, Language two. ERIC, 1982.

[8] J. Harmer, The practice of English language teaching. Harlow: Pearson Longman, 2007. 